\title{
FIRST RECORD OF RHYNCHOTHERIUM BLICKI (FRICK, 1933) FOR THE LATE CENOZOIC OF COSTA RICA
}

\author{
César Alberto Laurito Mora $^{1 *}$ \& Ana Lucía Valerio Zamora ${ }^{2}$ \\ ${ }^{1}$ Instituto Nacional de Aprendizaje, Núcleo de Turismo, \\ Apartado postal 203-2200, Coronado; San José, Costa Rica \\ E-mail: cesar_laurito@racsa.co.cr \\ ${ }^{2}$ Departamento de Historia Natural, Museo Nacional de Costa Rica \\ Apartado Postal 749-1000, San José - Costa Rica \\ E-mail: alvalerio@costarricense.cr
}

*Autor para contacto: cesarlaurito@ice.co.cr

(Recibido 25/05/05; aceptado 20/07/06)

\begin{abstract}
The genus Rhynchotherium has been described as a fossil for the Upper Miocene of Guatemala and volcanic deposits of Nicaragua, the Upper Miocene and Pliocene fluvial sediments of El Salvador and Honduras, but this is the first time it is recorded from Costa Rica. The material described includes a partially preserved skull with three upper molars. The material has been collected from a single locality, Santa Rita, near San Vito Town in the Puntarenas Province.

Key words: Gomphotheriidae, Rhynchorostrinae, Lower Pliocene, Paso Real Formation, Costa Rica.
\end{abstract}

RESUMEN: El género Rhynchotherium ha sido descrito para: el Mioceno Superior de Guatemala y los depósitos volcánicos de Nicaragua; en sedimentos fluviales del Mioceno Superior y Plioceno de El Salvador y Honduras. Esta es la primera vez que se registra en Costa Rica un cráneo parcialmente conservado de Rhynchotherium con tres piezas dentales. El material procede de la Localidad de Santa Rita, en las proximidades del pueblo de San Vito en la Provincia de Puntarenas.

Palabras clave: Gomphotheriidae, Rynchorostrinae, Plioceno Inferior, Formación Paso Real, Costa Rica. 


\section{INTRODUCTION}

In 1859, Leidy described a mastodon molar that came from the locality of Tambla in Honduras, this constituted the first paleovertebrate record of Central America. Later on, Osborn (1936) illustrated and described again the molar of Tambla and determined that it belonged to a mastodon of the genus Rhynchotherium.

Frick (1933) had described from Honduras two genera and new species of mastodons Blickotherium blicki and Aybelodon hondurensis, from the locality of Tapasuma, Gracias a Dios. Webb \& Tessman (1968), according to the evidence available at the moment, suggested these taxa are synonymous and included them in the genus Rhynchotherium as R. blicki. Tobien (1973) makes the observation that B. blicki probably constitutes a young specimen of A. hondurensis. Later on, Webb \& Perrigo (1984) described several records of Rhynchotherium blicki for the Late Miocene of Honduras and El Salvador.

Laurito (1988) points out the finding of an incomplete lower jaw ramus without molars of a mastodon, in which the alveoli of the lower tusks can be observed; and thus confirms its tetrabelodont nature. Therefore, it was about the most southern Rhynchotherium sp. recorded at that time which came from the locality of Las Lapas in Nicaragua.

Lucas \& Alvarado (1995) described a young specimen of $R$. Blicki in the Herrería Formation of the Late Miocene Lower Pliocene of eastern Guatemala.

Other than Rhynchotherium blicki, other proboscideans were described from Central America, e.g. Cuvieronius hyodon by Laurito (1988.); a mastodon Mammut americanum described by Lucas \& Alvarado (1991) for the Pleistocene of San Pedro Sula, Honduras (this finding is mentioned by Prado et al. (2004). However, the source is not mentioned), and the Elephantidae, Mammuthus columbi, from the Central Pacific coast of Costa Rica represents the most southern record for this species in Central America (Laurito, 1988 y Lucas et al., 1997).
Espinosa (1976) cites for the Paleoindian locality of El Bosque in Nicaragua, the presence of the genus Stegomastodon, based on a very fragmented molar. Moreover, Reshetov (1982) pointed out this record should be revised. Therefore, such preliminary determination was never confirmed and it could be very possible that it would correspond to Cuvieronius. In spite of the importance of the archeological site of El Bosque, its paleontology was underestimated. In fact, most of the paleontological material from this locality has been lost.

The Rhynchotherium are longirostrines and tetrabelodont mastodons (with four tusks) originated from gomphotheriids that migrated from Asia to North America.

The objective of the present study is to describe the first record of Rhynchotherium for Costa Rica.

The site is located in the coordinates Lambert 308.700 - 574.75 of the Topographic Sheet Cañas Gordas, number 3642 III, scale 1:50,000 from the National Geographic Institute of Costa Rica. The area belongs to Coto Brus, canton No 8 of the Province of Puntarenas, specifically to the ESE of the district of Limoncito near the village of Santa Rita (Fig.1).

\section{GEOLOGY}

The subject of study comes from the Paso Real Formation, specifically from the Río Boquilla Unit. Mora (1979) subdivides this formation in two units: El Brujo and Mano de Tigre, Garita (1988) described a new informal unit denominated Río Boquilla that also overlies with unconformity the marine sediments of the Curré Formation.

Its best outcrop is located in the Boquilla river, to the northeast of Jabillo of Coto Brus. Garita (1988) describes it as a cyclic alternation of sandstone, mudstones and conglomerates, with a thickness of about $800 \mathrm{~m}$, and divides this unit into four lithofacies: fine and coarse sandstones, mudstones and conglomerates of pebbles, in which it is common to find carbonized wood. 

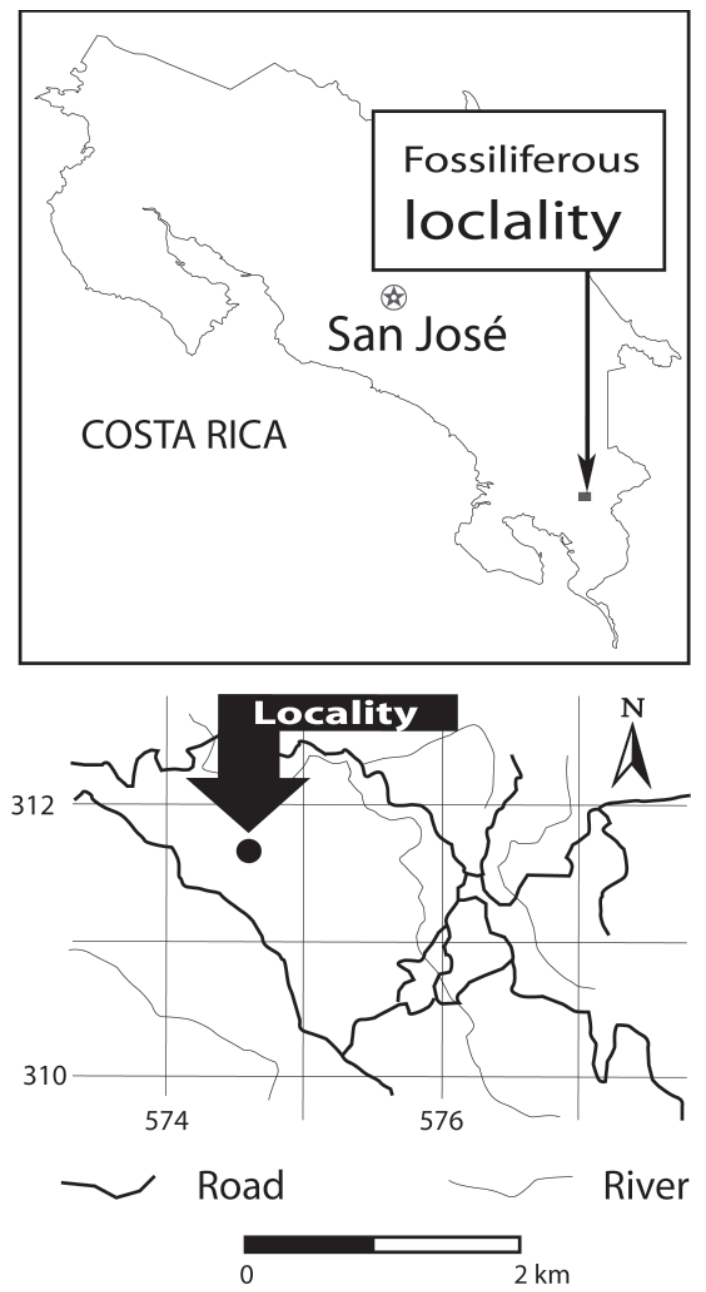

Fig. 1: Map of the locality of Santa Rita, Canton of Coto Brus, Puntarenas, Costa Rica.

The author explains the sedimentary environment of this unit as fluvial sequences, due to the presence of conglomerate deposits on fluvial channels associated with anastomosed rivers because of the predominance of laminated sands with cross-stratification. Murillo (1998) explains that some level of the unit was deposited in a shallow marine environment (foreshore) due to the presence of sedimentary concretions and hard grounds.

The sedimentology of the Río Boquilla Unit, according to our field observations, is explained as fluvial and lacustrine facies associated with "Fan Deltas" deposits close to the ancient coastal lines. These sedimentary deposits are overlying, through erosive hiatus, the marine sediments of the Curré Formation. Another interpretation of this could be a "Fan Delta" Deposit that corresponds to the top of the Curré Formation.

\section{TAPHONOMY}

The recovered specimen is a partially preserved skull covered by a concretion of conglomeratic fine pebbles, strongly cemented. The conglomerate corresponds to the Río Boquilla Unit and suggests a fluvial point bar deposit associated to a Fan Delta; the reason why the skull might have been transported previously to being definitely buried. The skull is associated with a horse premolar that confirms an allotopic burial.

\section{SYSTEMATIC}

Order PROBOSCIDEA (Illiger, 1811)

Family GOMPHOTERIIDAE (Cabrera, 1929) Subfamily RHYNCHOROSTINAE (Osborn, 1918)

\section{Genus RHYNCHOTHERIUM (Falconer, 1856)}

Mastodonts with long jaws and elongated symphysis; lower rounded tusks with flat inner surface and with an enamel band in the external surface (non helicoid). The upper tusks also show non-helicoid enamel bands and, in general, a pillar structure can be observed on the external cement layer. In some species, it is possible to see a featherly- pattern on the edge of the dentine with the enamel.

The molars show four lophos and lophids. The first lopho is much wider than the following three. The lophos and lophids are composed by ellipses and simple trefoils. 


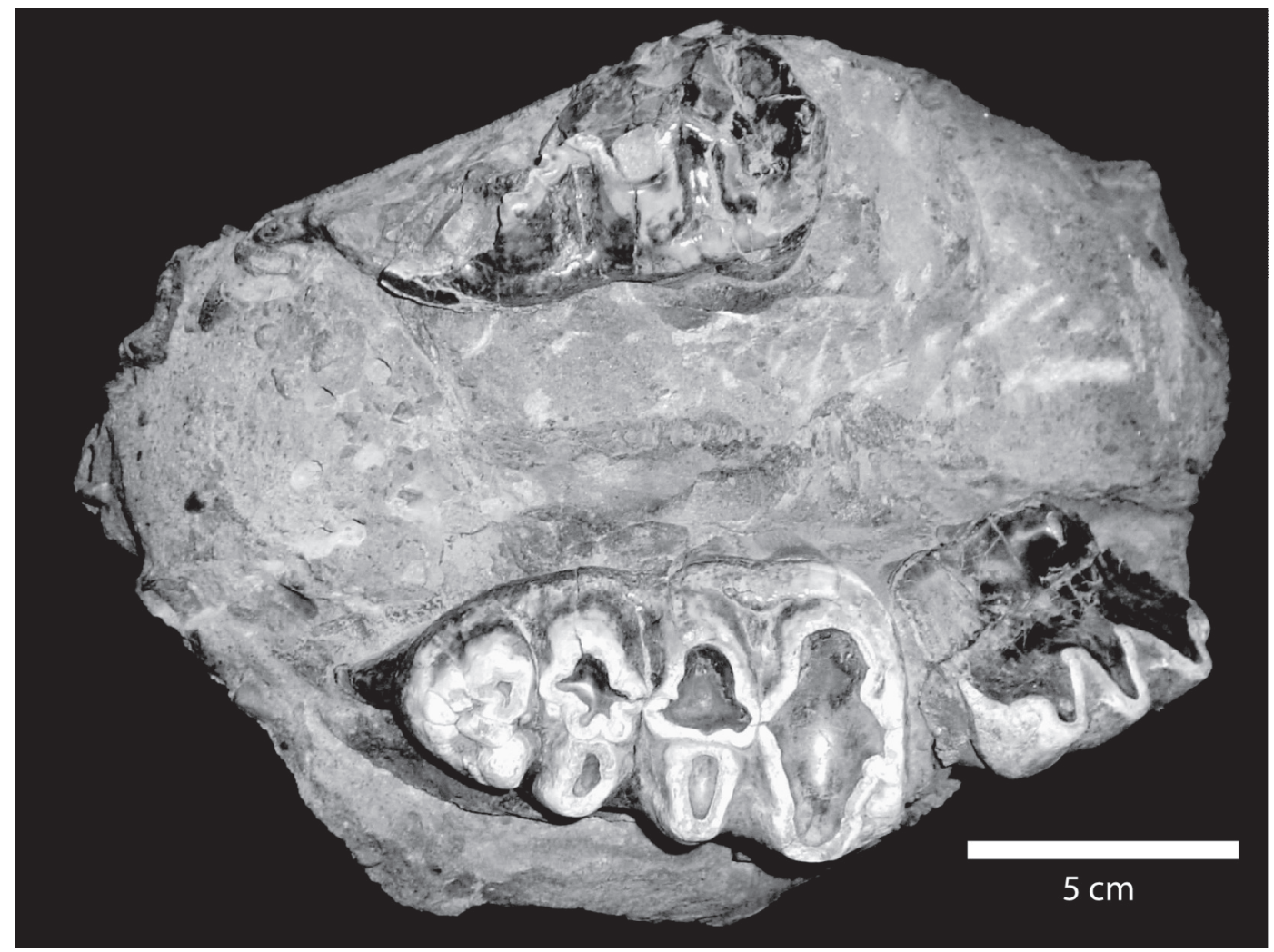

Fig. 2: partial skull of Rhynchotherium blicki (Frick, 1933) from Santa Rita, housed at the National Museum of Costa Rica under the code CFM-1424 (palatal view).

Species Rhynchotherium blicki (Frick, 1933)

\section{Material:}

An incomplete skull with the maxilla and palatal region partially preserved with three upper molars, the ${ }^{2} \mathrm{M}$ and the ${ }^{3} \mathrm{M}$, and the $\mathrm{M}^{3}$, and a zygomatic bone separated from the skull, all housed under the code CFM-1424 (Fig. 2). Besides, the frontal region of the skull with part of the alveoli of the upper tusks are also observed.

\section{Description:}

The ${ }^{2} \mathrm{M}$ is strongly worn with an occlusal pattern composed by three lophos and these by trefoils very wide and fused, its messio-distal length is of $110.5 \mathrm{~mm}$. and its vestibule-lingual width is of $81.0 \mathrm{~mm}$.

The ${ }^{3} \mathrm{M}$ shows an intermediate wearing stage with four and a half lophos; the fourth lopho is very reduced and presents a labial cingulum. The third lopho is composed by a short and simple ellipse, and by a trefoil with 5 lobulations, the second one, with an advanced stage of wearing, presents a trefoil of bell-shaped triangular silhouette and an ellipse of very simple contour. Finally, the first lopho is very worn with a fusion of the labial ellipse and the lingual cone. Its messio-distal length is of $154 \mathrm{~mm}$. and its vestibule-lingual width is of $79.5 \mathrm{~mm}$.

The $\mathrm{M}^{3}$ is very fragmented and it does not allow to obtain reliable biometrical data. However, it shows a wearing stage similar to the ${ }^{3} \mathrm{M}$, and as in this last one, a cord in the lingual edge of the crown can be observed. 


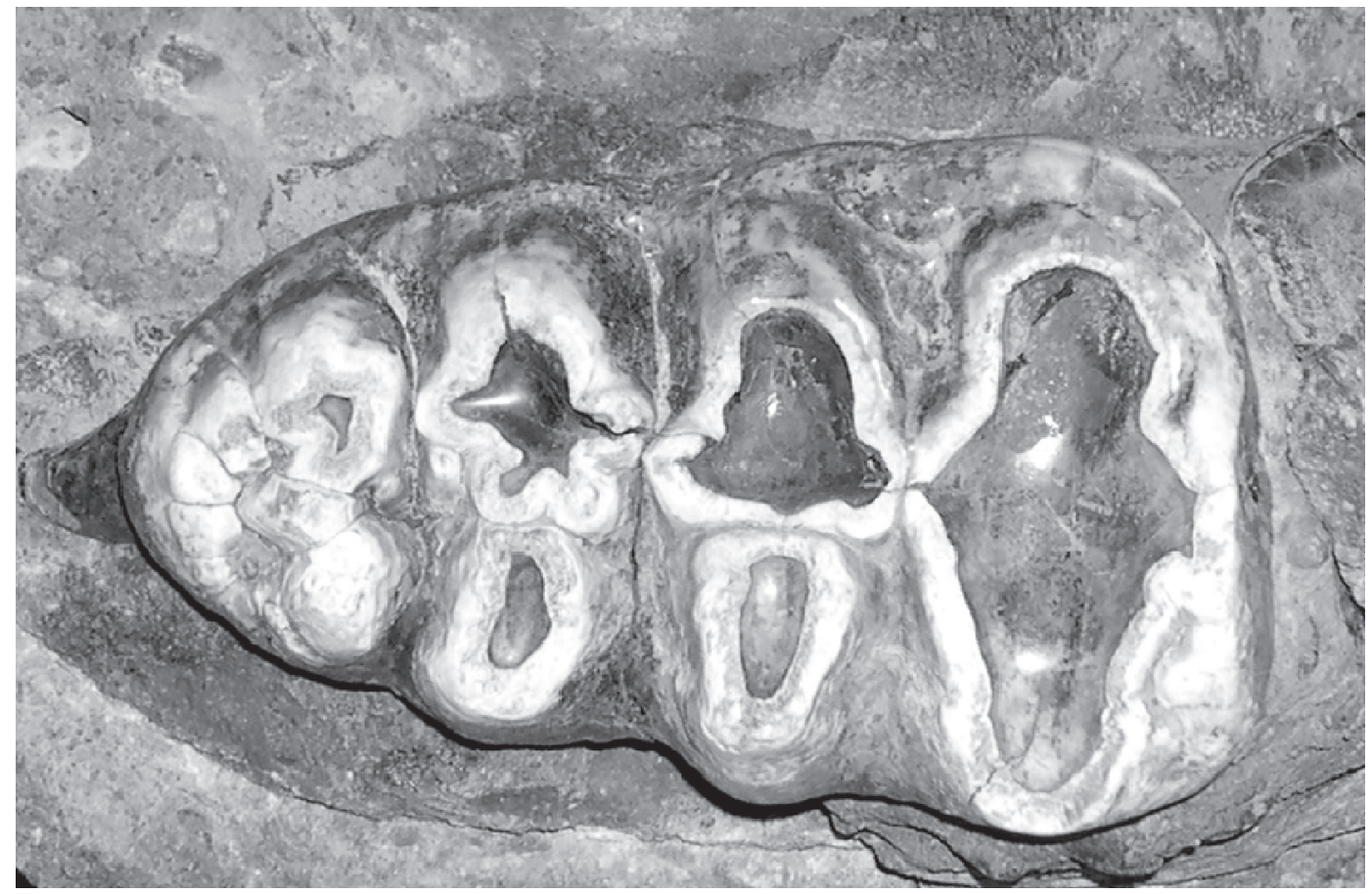

Fig. 3: detail of the occlusal surface of the ${ }^{3} \mathrm{M}$ of Rhynchotherium blicki (Frick, 1933), showing an intermediate wear stage with four and a half lophos.

Part of the temporal crest, the nasal bones, and the pre maxilla zone can be also observed. Besides, part of the zygomatic bone is separated from the skull.

\section{Discussion}

The mastodon of Santa Rita corresponds to an adult specimen, evidenced by the advanced worn of the ${ }^{2} \mathrm{M}$ and the moderate wearing of the ${ }^{3} \mathrm{M}^{3}$. Moreover, the small size of the skull and the molars confirm the genus Rhynchotherium.

When analyzing the dimensions of the second lopho of the $3 \mathrm{M}$, which width is of $79.5 \mathrm{~mm}$ and its ante-posterior length reaches $154 \mathrm{~mm}$, it can be confirmed that these measures correspond to the length and width described by Web \& Perrigo (1984, see table 1) for the specimens of El Salvador and Honduras. There is no doubt that this specimen belongs to the species Rhynchotherium blicki (Frick, 1933).
The second molar shows three lophos more or less uniform; the third molar shows four lophos, the lophos three and four have a tortuous pattern of the lingual trefoils, and the first one is very wide in comparison to the other lophos, which are noticeably much narrower; this is another characteristic of the genus Rhynchotherium. If we compare the third molars of Santa Rita and Tambla $\left(\mathrm{M}^{3}\right)$, it is noticeable that the pattern of the trefoils of the third lopho and the general configuration of the molar are almost exact (Figs. 3 and 4). The length, the pattern of trefoils and their arrangement lead to determine the species of Santa Rita as Rhynchotherium blicki (Frick, 1933).

\section{Paleobiogeographic distribution}

R. blicki (Frick) has been recorded for the Late Miocene of the Herrería Formation in the east of Guatemala (Lucas \& Alvarado, 1995). 


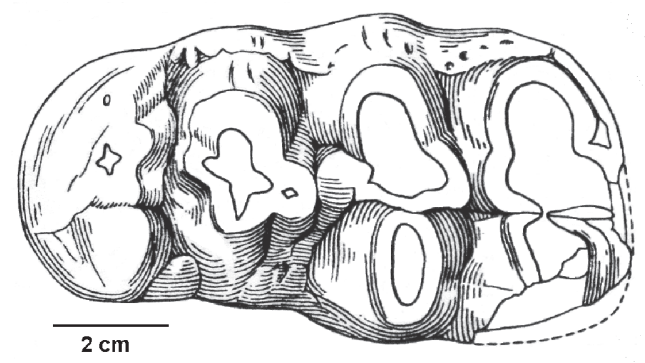

Fig. 4: ${ }^{3} \mathrm{M}$ of Rhynchotherium sp. from Tambla Honduras described by Leidy (1859) and illustrated by Osborn (taken from Osborn, 1936).

Probably, the Rhynchotherium found in the volcanic, sedimentary series of the Coyol Group in Cerro Las Lapas to the Northwest of Dario, Nicaragua, belongs to the species R. blicki (Frick). Even though these series are considered to belong to the Middle Miocene (Laurito, 1988), these might probably be a little younger, from the Upper Miocene.

The species $R$. blicki (Frick) has been described for the Lower Pliocene of the Gracias Formation, in the localities of Tapasuma and Gracias in Honduras (Frick, 1933; Olson \& McGrew, 1941). On the contrary, Webb \& Perrigo (1984) suggested an Upper Miocene age for these findings.

This species has been also described for the Upper Miocene of the locality of Corinto, Department of Morazán, in the Northeast of El Salvador (Webb \& Perrigo, 1984).

The tooth of the locality of Tambla in Honduras, described before by Leidy (1859) was redefined and illustrated by Osborn (1936); it supposedly comes from an ignimbrite deposit from the Pleistocene of El Salvador according to Webb \& Perrigo (1984).

The sediments of the Gracias Formation are fluvial and were deposited inside a graben that according to Webb \& Perrigo (1984) overlies pyroclastic deposits of Upper Miocene age.

On the other hand, David Webb estimated the age of the pyroclastic deposits where the tooth of Tambla in Honduras probably came from as Pleistocene. However, data are lacking; therefore, it could be possible that we are dealing with deposits slightly much older, probably from the Upper Pliocene.
According to what has been said, it is possible that the species R. blicki (Frick) has a biochronostratigraphic range from the Upper Miocene to the Lower Pliocene-Upper Pliocene?, which would correspond to the temporal range of the genus Rhynchotherium usually described in the literature (Webb, 1984).

\section{Age}

As it was mentioned before, Webb \& Perrigo (1985) assumed an Upper Miocene age (Hemphillian) for the formations with $R$. blicki (Frick), due to the relationship of this gomphotere with the horse Calippus hondurensis. In spite of it, Hulbert (1988) explains that the Salvadorian specimens referred to as $C$. hondurensis are larger than the original topotypes and have a much more deeper ectoflexid, and concludes that this does not represent $C$. hondurensis, but an equine clade member.

It is difficult to establish an exact age for the skull of the R. blicki (Frick) of Santa Rita. However, according to the biostratigraphic range known for this species and the stratigraphic position of the Río Boquilla Unit into the Paso Real Formation, a Lower Pliocene age is assumed equivalent to the Late Hemphillian or Early to Late Blancan.

The finding of the Rhynchotherium blicki (Frick, 1933) is the first paleontological evidence that allows to establish a Lower Pliocene tested age for Paso Real Formation.

\section{CONCLUSIONS}

The first find for Costa Rica of the Rhynchotherium blicki (Frick, 1933) is registered. It also constitutes the most austral evidence of this endemic species of Central America. Based on this finding, it is possible to conclude a Lower Pliocene age for the fluvial sediments of Río Boquilla Unit from Paso Real Formation.

The paleobiogeographic distribution of the species Rhynchotherium blicki (Frick, 1933) 
would be extended from the east of Guatemala to the south of Costa Rica, near the Panama border.

Finally, the number of genera and species of probocideans registered for Costa Rica have increased to three: Mammuthus columbi; Cuvieronius hyodon and Rhynchotherium blicki. Rhynchotherium blicki being the oldest record of a terrestrial mammal for Costa Rica known up to this date.

\section{ACKNOWLEDGEMENTS}

Our most sincere gratitude to Francisco Corrales Ulloa, Director of the National Museum of Costa Rica, for allowing us to study the specimen; to Alfredo Duncan, of the Department of Protection of the Cultural Patrimony, who worked in the consolidation and cleaning of the specimen; to Luis Diego Gómez (O.T.S.) who revised the text and the translation to English language and to the family Granado Rojas for allowing us to recovered the fossils found in its farm. This research was made possible by the cooperation of the Organization for Tropical Studies, ESCOGroup, San Jose, and private donations.

\section{REFERENCES}

CARRILLO, M., 1998. Estudio geológico de Valle de Limoncito y alrededores, Coto Brus, Pacífico sur de Costa Rica.- 99 págs. Inf. Camp. Geol. ECG-UCR.

ESPINOSA, J., 1976: Excavaciones arqueológicas en el Bosque. Informe 1.- 84 págs. Departamento de Antropología e Historia, Instituto Geográfico Nacional Ministerio de Obras Públicas.

GARITA, E. 1998. Estudio geológico aplicado entre Tablas, Bajo Coto y alrededores. cantón de Coto Brus, Prov. de Puntarenas, Costa Rica.109 págs. Inf. Camp. Geol. ECG-UCR.
FRICK, C., 1933: New remains in trilophodont-tetrabelodont mastodonts.- American Museum of Natural History, Bulletin 59: 505-652.

HULBERT, R.C., 1988: Calippus and Protohippus (Mammalia, Perissodactyla, Equidae) from the Miocene (Barstovian-Early Hemphillian of the Gulf Coastal plain).Bull. Florida State Mus. Biol. Sci.: 32(3): 221-340.

LAURITO, C., 1988: Los proboscidios fósiles de Costa Rica y su contexto en la América Central.- Vínculos 14(1-2): 29-58.

LEIDY, J., 1859: On mastodon tooth from Honduras.- Proceedings of the Academy of Natural Sciences of Philadelphia, 2: 91.

LUCAS, S.G. \& ALVARADO, G.E., 1991: El hallazgo más austral de un Mammut americanum: el caso del mastodonte de San Pedro Sula, Honduras.- Rev. Geol. Amér. Central, 13: 85-89.

LUCAS, S.G. \& ALVARADO, G.E., 1995: El proboscidio Rhynchotherium blicki (Mioceno Tardío) del Oriente de Guatemala.- Rev. Geol. Amér. Central, 18: 19-24.

LUCAS, S.G.; ALVARADO, G.E. \& VEGA, E. 1997. The Pleistocene mammals of Costa Rica.- Journal of Vertebrate Paleontology, 17 (2):413-427.

MORA, S., 1979: Estudio geológico de una parte de la región sureste del Valle del General, Provincia de Puntarenas, Costa Rica.- 157 págs. Tesis de Lic. ECG-UCR, 157.

MURILLO, J., 1998: Estudio geológico de San Miguel y alrededores, Cantón de Coto Brus, Puntarenas.- 99 págs. Inf. Camp. Geol. ECG-UCR. 
OLSON, E.C. \& MCGREW, P.O., 1941: Mammalian fauna from the Pliocene of Honduras.- Bull. Geol. Soc. of America 52: 1219-1244.

OSBORN, H.F., 1936: Proboscidea. A monograph of the discovery, evolution, migration and extinction of the mastodons and elephants. Vol. 1 Moeritherioidea, Deinotheroidea, Mastodontoidea.- The American Museum of Natural History, New York, 1: 1-802.

PRADO, J.S., ALBERDI, M.T., AZANZA, B. \& SÁNCHEZ, B., 2005: The Pleistocene Gomphoteriidae (Proboscidea) from South America.- Quaternary International 126-128: 21-30

RESHETOV, V., 1982: Reporte preliminar sobre la observación de la paleontología en Nicaragua.- 13 págs. Inst. Paleontol. Acad. Cienc. U.R.R.S., Moscú:
TOBIEN, H., 1973: On the Evolution of Mastodons. Notizbl. Hess. Landes. Bodenforsch.- Zu Wiesbaden 101: 202276.

WEBB, S.D., 1984: Ten million years of mammals extinctions in North America.- En MARTIN, P.S. \& KLEIN, R.G. (Eds.): Quaternary Extinctions, A prehistoric revolution.- The University of Arizona Press: 189-210.

WEBB, S.D. \& PERRIGO, S.C., 1984: Late Cenozoic vertebrates from Honduras and El Salvador.- Journal of Vertebrate Paleontology, 4(2): 237-254.

WEBB, S.D. \& TESMAN, N., 1968: A Pliocene vertebrate fauna from Manatee County, Florida.- American Journal of Science 266:777-811. 